\title{
Evaluating quality of care for patients with type 2 diabetes using electronic health record information in Mexico
}

\author{
Ricardo Pérez-Cuevas ${ }^{*}$, Svetlana V Doubova ${ }^{2}$, Magdalena Suarez-Ortega ${ }^{2}$, Michael Law ${ }^{3}$, Aakanksha H Pande ${ }^{4}$, \\ Jorge Escobedo ${ }^{5}$, Francisco Espinosa-Larrañaga ${ }^{6}$, Dennis Ross-Degnan ${ }^{4}$ and Anita K Wagner ${ }^{4}$
}

\begin{abstract}
Background: Several low and middle-income countries are implementing electronic health records (EHR). In the near future, EHRs could become an efficient tool to evaluate healthcare performance if appropriate indicators are developed. The aims of this study are: a) to develop quality of care indicators (QCls) for type 2 diabetes (T2DM) in the Mexican Institute of Social Security (IMSS) health system; b) to determine the feasibility of constructing QCls using the IMSS EHR data; and c) to evaluate the quality of care (QC) provided to IMSS patients with T2DM.

Methods: We used a three-stage mixed methods approach: a) development of QCls following the RAND-UCLA method; b) EHR data extraction and construction of indicators; c) QC evaluation using EHR data from 25,130 T2DM patients who received care in 2009.

Results: We developed $18 \mathrm{QCls}$, of which 14 were possible to construct using available EHR data. QCls comprised both process of care and health outcomes. Several flaws in the EHR design and quality of data were identified. The indicators of process and outcomes of care suggested areas for improvement. For example, only $13.0 \%$ of patients were referred to an ophthalmologist; $3.9 \%$ received nutritional counseling; $63.2 \%$ of overweight/obese patients were prescribed metformin, and only $23 \%$ had HbA1c $<7 \%$ (or plasma glucose $\leq 130 \mathrm{mg} / \mathrm{dl}$ ).

Conclusions: EHR data can be used to evaluate QC. The results identified both strengths and weaknesses in the electronic information system as well as in the process and outcomes of T2DM care at IMSS. This information can be used to guide targeted interventions to improve QC.
\end{abstract}

\section{Background}

The worldwide prevalence of type 2 diabetes (T2DM) is on the rise, especially in low and middle-income countries (LMIC), reaching up to $14 \%$ of the adult population in Mexico [1], twice the current global prevalence [2]. T2DM poses considerable challenges to healthcare systems because it is among the leading causes for ambulatory care, hospital admissions and death [3]. In Mexico, quality of T2DM care has been suboptimal $[4,5]$, health outcomes poor, [6] and costs of T2DM care and its complications are on the rise [7].

Healthcare for patients with diabetes has both individual and health system goals. At the individual level, the

\footnotetext{
*Correspondence: rperez@iadb.org

${ }^{1}$ Division of Social Protection and Health, Inter-American Development Bank, Washignton, USA

Full list of author information is available at the end of the article
}

goal is to achieve the best possible health outcomes. At the health system level, the goal is to provide accessible, high quality, effective, and efficient care. Information about progression of the disease and processes of care for patients with T2DM over time is required to assess whether goals are being accomplished.

The electronic health record (EHR) is a tool that can provide necessary input for dynamic improvement of systems for chronic care by a) supporting clinical decisions at the point of care; b) providing routine data to evaluate the quality of care (QC); and c) facilitating longitudinal systems research and efficient information sharing for dynamic care improvement $[8,9]$. In publicly financed health care systems, EHR may also help improve transparency and accountability.

LMIC are beginning to use EHR [10]. Argentina, Costa Rica and Peru use EHR in circumscribed settings, such

\section{()

(C) 2012 Perez-Cuevas et al.; licensee BioMed Central Ltd. This is an Open Access article distributed under the terms of the Creative Commons Attribution License (http://creativecommons.org/licenses/by/2.0), which permits unrestricted use, distribution, and reproduction in any medium, provided the original work is properly cited. 
as individual clinics or hospitals, or for research purposes [11]. Mexico was the first Latin American country that introduced an EHR on a large-scale at the Mexican Institute of Social Security (IMSS). IMSS is a nationwide institution providing social security and healthcare benefits to approximately $47 \%$ of the 112 million Mexican people. In 2003, IMSS began to introduce its EHR and evidence-based clinical guidelines to improve performance of its family medicine clinics [12]. The IMSS EHR became a key component of the institutional information system, which also includes administrative, member enrollment, pharmacy and other databases.

The IMSS EHR comprises information that could be used to improve the quality, efficiency and continuity of care; however, it has not been fully used for these purposes. Little is known about the quality of the data that are routinely captured and what relevant quality of care indicators (QCIs) can be constructed based on routine data.

T2DM is a complex and dynamic problem that requires a steady flow of information for healthcare providers to guide their clinical and managerial decision-making. The objectives of this project were: a) to develop QCIs for T2DM in the IMSS health system; b) to determine the feasibility of constructing QCIs using IMSS EHR data; and c) to evaluate the QC provided to IMSS patients with T2DM.

\section{Methods \\ Design}

We used data from four large family medicine clinics located in Mexico City with a catchment area of 585,536 people. Each clinic had between 15 and 30 physician offices, a laboratory, and a pharmacy.

IMSS' EHR consists of several linked databases which include information on appointments; medical history; physical examination; clinical encounter notes; aspects of care and progress for patients with specific conditions (diabetes, antenatal care, hypertension); social work, occupational health, dietary, and preventive care services. Clinical encounter notes capture the reason for the visit, symptoms, signs, diagnoses (ICD-10 coded), orders for laboratory tests, electronic prescriptions, and disability and referral information. Data fields contain free-text, numeric, or pre-coded, menu-driven entries. Electronic prescriptions (by menu-driven generic product name) are linked to the IMSS essential list of medicines and the clinic's pharmacy inventory. The laboratory database is linked to the menu-driven, coded catalog of IMSS laboratory exams and contains laboratory test orders. Laboratory examination results reside in different, unlinked databases.

\section{Stage 1: Development of QC Indicators}

To design and validate T2DM QCIs, we used the modified version of the RAND/UCLA Appropriateness
Method, which comprises scientific evidence and expert opinion $[13,14]$.

First, we performed a systematic search and review of the literature on QCIs for T2DM using Marshall's proposed method [15]. We searched the following databases: Medline, Ovid, Cochrane Library, National Guideline Clearinghouse, CMA Infobase: Clinical Practice Guidelines, TRIP database, Institute for Clinical System Improvement, ACP Guideline website, American Academy of Family Physicians, NHS Evidence - National Library of Guidelines, and IMSS-Clinical Guidelines [16]. The keywords were "type 2 diabetes mellitus", "quality of care indicators", "clinical guidelines," and "family medicine" or "primary care services," "diagnosis" and "treatment".

The review focused on evidence-based care processes shown to increase the likelihood of achieving the best possible clinical outcomes, following the criteria proposed by Saslow et al. [17]. The review included indicators from the Healthcare Effectiveness Data and Information Set (HEDIS) [18], as well as those developed by the RAND Health Research and Institute for Clinical System Improvement (ICSI) teams. Indicators for four basic components of care for T2DM patients were defined a) timely screening for complications and comorbidity; b) nonpharmacological treatment; c) pharmacological treatment; and d) health outcomes.

Next, we assembled a panel of 8 experts. Panel members had experience in treating T2DM patients, in conducting clinical and health systems research, and in developing clinical guidelines. Each panelist received information about the study objectives, methodology, literature review and set of preliminary indicators. Panelists rated indicators on validity and feasibility according to Shekell's criteria [19] by assigning a value from 1 to $9(1=$ definitely not valid or not feasible and $9=$ definitely valid or feasible). An indicator was valid when it assessed a process of care for which there was enough scientific evidence to support the relationship between the specific process and a potential health benefit or the assumption that health care professionals who perform specific care aspects provide better quality of care than those who do not. An indicator was feasible when there was a high probability that the required information to construct the indicator would be available in a typical health record, or, if not, the lack of information would represent poor quality of care. Panelists used these criteria to rate each proposed indicator. An indicator was valid and feasible if its mean score was $\geq 7$ on each domain. Panelists participated in two e-mail rounds of ranking and two face-to-face panel meetings.

\section{Stage 2: Extraction of routine EHR data to construct the QCls}

To evaluate whether the indicators defined in Stage 1 could be constructed, we extracted data from a cohort 
of all continuously enrolled patients in the four study clinics. All patients with a diagnosis of T2DM according to the International Classification of Diseases, Tenth Revision (ICD-10) codes E111-E119, E140-E149, and E14X in one of three EHR diagnosis fields, who were older than 19 years of age and visited a family doctor at least once during 2009 were eligible.

For the cohort of patients with T2DM, we extracted EHR and laboratory data from the participating Family Medicine Clinics (FMCs) for calendar year 2009 and created an analytic dataset with the following variables:

a. Variables from the EHR: general patient characteristics (age, sex, schooling, marital status, membership (subscriber/dependent and employment status); medical history (age at onset and duration of T2DM, history of hypertension, other cardiovascular diseases, or dyslipidemia; chronic complications [peripheral vascular disease, nephropathy, retinopathy, and peripheral neuropathy]; physical measurements (weight, height, and blood pressure); nutritional status (at the beginning and at the end of the year) as measured by body mass index (BMI) (underweight $\left[\mathrm{BMI}<18.5 \mathrm{~kg} / \mathrm{m}^{2}\right]$, normal weight [BMI 18.5 - $24.9 \mathrm{~kg} / \mathrm{m} 2$ ], overweight [BMI 25.0 $\left.29.9 \mathrm{~kg} / \mathrm{m}^{2}\right]$, obese $\left[\mathrm{BMI} \geq 30.0 \mathrm{~kg} / \mathrm{m}^{2}\right]$ ); clinical care (number of visits to the family doctor, referral to an ophthalmologist and/or dietitian); prescriptions (insulin and oral hypoglycemic drugs [metformin, glibenclamide, acarbose, rosiglitazone or pioglitazone]; other drugs [acetylsalicylic acid, statins and angiotensin converting enzyme inhibitors or angiotensin-receptor blockers]); laboratory tests ordered.

b. Variables from the laboratory database: dates and measured values of hemoglobin A1c (HbA1c), fasting blood glucose, and total cholesterol.

We queried the relational EHR and laboratory database tables of each clinic using standard queries in structured query language (SQL) to retrieve data from tables and create a new analytic database. We then assessed the data for completeness, consistency and accuracy. We predefined non-plausible lowest values for the following variables: blood pressure (systolic blood pressure $<50 \mathrm{mmHg}$ or $>250 \mathrm{mmHg}$ and diastolic blood pressure $<40 \mathrm{~mm} \mathrm{Hg}$ or $>200 \mathrm{mmHg}$ [20]); height $(<130 \mathrm{~cm}$ or $>250 \mathrm{~cm})$, weight $(<30 \mathrm{~kg}[21]$ or $>200 \mathrm{~kg}), \mathrm{HbA1C}(<3.0)$, fasting blood glucose $(<37 \mathrm{mg} / \mathrm{dl})$; and total cholesterol $(<100 \mathrm{mg} / \mathrm{dl})$. All non-plausible values were excluded from the analysis. We used the SAS statistical package (V9.2) to construct complex variables from the extracted data. We validated the extracted data by comparing a sample of 80 records in the EHR system with our final dataset. The comparisons were made reviewing data from individual EHR with the extracted data.

\section{Stage 3: Evaluation of T2DM quality of care}

We described QC indicators by family medicine clinic. We also characterized clinics by available health personnel (number of medical doctors, nutritionists, social workers, and nurses) and number of examination rooms.

The IMSS' National Commissions of Research and Ethics reviewed and approved the study protocol.

\section{Results}

\section{Stage 1: Development of QC Indicators}

Table 1 shows the results of the indicator evaluation process. Scores ranged from 5.3 to 8.7. Based on the predefined threshold of 7 , the panel discarded 5 and accepted 18 indicators; some indicators scored high in validity, but were not feasible and were then modified. For example, HbA1c test results were not available in all clinics. Therefore, the outcome indicator was modified from "T2DM patients who had HbA1c $<7 \%$ " to: "T2DM patients who had HbA1c $<7 \%$, or fasting blood glucose $\leq 130 \mathrm{mg} / \mathrm{dl}$ in the last three measurements". Similarly, the LDLcholesterol indicator was replaced by an indicator based on total cholesterol, while the indicator of screening for microalbuminuria was discarded.

\section{Stage 2: Extraction of routine EHR data to construct QCls} The final list (Table 1) shows that 14 indicators were programmable with data from the EHR and laboratory databases. We decided that four indicators could not be reliably constructed because information was only available in free-text fields with wide variability in entries. There was a high percentage of missing data for employment, schooling, marital status, and duration of diabetes. Also, weight, height and blood pressure had between 5\% and $24 \%$ non-plausible values.

\section{Stage 3: Evaluation of T2DM quality of care}

Table 2 presents the main characteristics of the four participating FMCs. There were 204 family doctors working in the clinics; 67 registered nurses, 86 auxiliary nurses, 6 dietitians, and 36 social workers. Three clinics had a separate department to conduct medical education activities. In 2009, the clinics covered 585,536 members and dependents, with 437,417 >20 years old; approximately 174,266 patients visited the clinics at least once during 2009, of whom 25,130 (14\% of patients) had a diagnosis of T2DM.

Table 3 presents the characteristics of the T2DM patients. Most (59\%) were women. The average age was 62.3 years. Nearly two in five patients had low education (39\% illiterate or primary school education only); almost half were married or lived with their partner. Nearly $30 \%$ were housewives; $17 \%$ were employed and 10\% were 
Table 1 Results from evaluation of candidate indicators

\begin{tabular}{|c|c|c|c|c|}
\hline Indicator & Validity & Feasibility & $\begin{array}{c}\text { Result of the } \\
\text { validation process }\end{array}$ & $\begin{array}{c}\text { Programmable ir } \\
\text { the EHR }\end{array}$ \\
\hline I. Process indicators & \multicolumn{2}{|c|}{ Average } & & \\
\hline \multicolumn{5}{|c|}{ A. Timely detection of T2D complications and comorbidity in the last year } \\
\hline 1. At least one measurement of $\mathrm{HbA} 1 \mathrm{c}$ & 8.7 & 7.8 & Accepted & Programmable \\
\hline 2. Comprehensive foot evaluation & 8.7 & 8.2 & Accepted & Programmable \\
\hline 3. Referral to the ophthalmologist & 8.3 & 7.7 & Accepted & Programmable \\
\hline 4. Screening for microalbuminuria through the ratio albumin/creatinine & 8.5 & 5.7 & Discarded & \\
\hline 5. Measurement of creatinine and rate of glomerular filtration & 8.7 & 5.3 & Discarded & \\
\hline 6. Screening for dyslipidemia by measuring total cholesterol in patients & 8.5 & 7.8 & Accepted & Programmable \\
\hline
\end{tabular}

\section{B. Non pharmacological treatment in the last year}

7. Smoking cessation counseling for current smokers

8. Advise to moderate alcohol consumption

9. Nutritional counseling provided by the nutrition service

10. Advise to practice aerobic physical exercise of moderate intensity, at least 150 minutes per week, unless contraindicated

11. Registration of adherence to dietary recommendations

12. Registration of adherence to aerobic physical exercise

\section{Pharmacological treatment in the last three visits}

13. Overweight/obese (BMl $\geq 25 \mathrm{~kg} / \mathrm{m}^{2}$ ) patients who received metformin, unless contraindicated*

14. Patients with $\mathrm{HbA} 1 \mathrm{c} \geq 8$, or with an average fasting blood glucose of $\geq 140 \mathrm{mg} / \mathrm{dl}$ in the last 3 months, who had registered: a) recommendations to modify their diet and physical exercise, b) referral to a social work group;

c) modification in their scheme of treatment.

15. Patients with $\mathrm{HbA} 1 \mathrm{c} \geq 8$, or with an average fasting blood glucose of $\geq 140 \mathrm{mg} / \mathrm{dl}$ in the last 3 months, who had registered adherence to the pharmacological treatment.

16. Patients with hypertension receiving inhibitors of angiotensin converting enzyme or angiotensin-receptor blocker, otherwise contraindicated**

17. Patients $>40$ years of age with one or more of the following risk factors: smoking, hypertension, dyslipidemia, receiving 75-150 mg/day of acetylsalicylic acid, unless contraindicated $d^{* * *}$

18. Patient with total cholesterol $>200 \mathrm{mg} / \mathrm{dl}$ and were prescribed statins, unless contraindicated ${ }^{* * *}$

$\begin{array}{lll}8.7 & 8.5 & \text { Accepted } \\ 8.7 & 6.3 & \text { Discarded }\end{array}$

Accepted

Discarded

Accepted

Accepted

Accepted

Accepted

Discarded

8.5

8.5

8.5

8.2

\section{Health outcomes indicators}

19. $\mathrm{HbA1c}<7 \%$ or fasting glucose $\leq 130 \mathrm{mg} / \mathrm{dl}$ in the last 3 measurements

20. Total cholesterol levels $<200 \mathrm{mg} / \mathrm{dl}$ in the last measurement

21. Blood pressure $<130 / 80 \mathrm{mmHg}$ in the last 3 measurements

22. Overweight/obese (BMI $\geq 25 \mathrm{~kg} / \mathrm{m}^{2}$ ) patients who lost $\geq 5 \%$ body weight in the last year

\section{Composed indicator of health outcomes}

23. Patients with $\mathrm{HbA} 1 \mathrm{c}<7 \%$, or fasting glucose $\leq 130 \mathrm{mg} / \mathrm{dl}$, total cholesterol levels $<200 \mathrm{mg} / \mathrm{dl}$ and blood pressure $<130 / 80 \mathrm{mmHg}$ in the last 3 measurements

$\begin{array}{llll}8.7 & 8.3 & \text { Accepted } & \text { Programmable } \\ 8.7 & 8.2 & \text { Accepted } & \text { Programmable } \\ 8.7 & 8.5 & \text { Accepted } & \text { Programmable } \\ 8.0 & 7.7 & \text { Accepted } & \text { Programmable }\end{array}$

8.5

7.5

Accepted

Programmable

${ }^{*}$ Contraindications to metformin: a) Renal failure b) respiratory or advanced liver failure c) congestive heart failure, coronary artery disease or advanced atherosclerosis; d) pregnancy; e) intolerance to metformin.

**Contraindications to inhibitors of angiotensin converting enzyme: intolerance and/or prior treatment failure.

***Contraindications to acetylsalicylic acid in doses of 75-150 mg/day: history of hypersensitivity to aspirin, peptic ulcer disease, and hemophilia.

${ }^{* * * *}$ Contraindications to statins: hypersensitivity to any component of the drug, active liver disease or unexplained persistent elevations of serum transaminases, pregnancy and lactation. 
Table 2 Population and clinic characteristics

\begin{tabular}{lccccc}
\hline Population affiliated with & \multicolumn{6}{c}{ FMC A FMC B } & FMC C FMC D & Total \\
\cline { 2 - 6 } the family medicine clinic & $\mathbf{n}$ & $\mathbf{n}$ & $\mathbf{n}$ & $\mathbf{n}$ & $\mathbf{n}$ \\
\hline Total number of members & 123,276 & 149,396 & 196,513 & 116,351 & 585,536 \\
Members per family doctor & 2,241 & 2,449 & 3,388 & 3,878 & 2,828 \\
Members $\geq 20$ years old & 95,303 & 120,579 & 143,796 & 77,739 & 437,417 \\
Members $\geq 20$ years old who & 45,703 & 53,370 & 46,270 & 28,923 & 174,266 \\
attended the clinic at least & & & & & \\
once in 2009 & & & & & \\
T2DM patients as percentage & 7184 & 6671 & 7256 & 4019 & 25130 \\
of members $\geq 20$ years old & $15.7 \%$ & $12.5 \%$ & $15.7 \%$ & $13.9 \%$ & $14.4 \%$ \\
who attended the clinic at & & & & & \\
least once in 2009 & & & & & \\
Health personnel and & & & & & \\
examining rooms & & & & 30 & 204 \\
Family doctors & 55 & 61 & 58 & 30 \\
Registered nurses & 14 & 26 & 14 & 13 & 67 \\
Ancillary nurses & 14 & 21 & 35 & 16 & 86 \\
$\begin{array}{l}\text { Dietitian } \\
\text { Social workers }\end{array}$ & 2 & 1 & 1 & 2 & 6 \\
$\begin{array}{l}\text { Number of family } \\
\text { doctors' offices }\end{array}$ & 9 & 11 & 9 & 7 & 36 \\
$\begin{array}{l}\text { Department of } \\
\text { medical education }\end{array}$ & 27 & 29 & 30 & 15 & 101 \\
\hline & & 1 & 1 & 0 & 3 \\
\hline
\end{tabular}

Source: Family medicine clinics 2009 electronic health record information.

retired. Most (76\%) patients were dependents of insured members.

Table 4 lists the clinical conditions and health care characteristics of the included patients. More than $16 \%$ of those reporting had diabetes for over 15 years; however, disease duration was mostly missing (44\%-77\%). Hypertension was the most frequent comorbidity (60\%). Approximately $31 \%$ of patients had a chronic complication, mostly peripheral vascular disease (14\%) followed by diabetic nephropathy (11\%). Only $15 \%$ had normal weight; $36 \%$ were overweight and $33 \%$ obese.

Patients with T2DM were regular users of health care services; on average, they had 8.8 visits in 2009. Between $10 \%$ and $20 \%$ of patients did not receive any hypoglycemic prescription; most (77\%) received 1 or 2 drugs. Metformin (37\%) and glibenclamide (46\%) were the most frequently prescribed medications.

Table 5 reports results for the quality of care indicators. There were wide variations among clinics. Two clinics had no HBA1c measurements, while the other two had limited availability. Indicators of timely detection of complications varied widely: between $5 \%-52 \%$ of patients received comprehensive foot evaluations; $5 \%-22 \%$ were referred to an ophthalmologist; and 46\%-70\% were screened for dyslipidemia. Only 4\% received nutritional counseling. Across clinics, metformin was prescribed (63\%) to a majority of overweight or obese patients; $57 \%$ of patients with
Table 3 Type 2 diabetes patients' general characteristics

\begin{tabular}{|c|c|c|c|c|c|}
\hline \multirow[t]{2}{*}{ Characteristics } & FMC A & FMC B & FMC C & FMC D & Total \\
\hline & $\begin{array}{c}n=7184 \\
\%\end{array}$ & $\begin{array}{c}\mathrm{n}=6671 \\
\%\end{array}$ & $\begin{array}{c}\mathrm{n}=7256 \\
\%\end{array}$ & $\begin{array}{c}n=4019 \\
\%\end{array}$ & $\begin{array}{c}n=25130 \\
\%\end{array}$ \\
\hline Female sex & 59.3 & 57.8 & 58.6 & 58.2 & 58.5 \\
\hline $\begin{array}{l}\text { Age, years, mean } \\
\text { (standard deviation) }\end{array}$ & $\begin{array}{l}62.9 \\
(12.9)\end{array}$ & $\begin{array}{c}64.3 \\
(12.8)\end{array}$ & $\begin{array}{l}61.8 \\
(12.8)\end{array}$ & $\begin{array}{l}58.5 \\
(12.4)\end{array}$ & $\begin{array}{l}62.3 \\
(12.9)\end{array}$ \\
\hline \multicolumn{6}{|l|}{ Age groups } \\
\hline$<30$ years & 0.6 & 0.3 & 0.7 & 0.9 & 0.6 \\
\hline 30-39 years & 3.4 & 3.1 & 4.0 & 5.2 & 3.8 \\
\hline 40-49 years & 11.2 & 9.7 & 12.6 & 16.8 & 12.1 \\
\hline 50-59 years & 23.8 & 21.0 & 24.4 & 31.2 & 24.4 \\
\hline $60-69$ years & 28.3 & 29.6 & 29.5 & 26.0 & 28.6 \\
\hline$\geq 70$ years & 32.7 & 36.3 & 28.8 & 19.9 & 30.5 \\
\hline \multicolumn{6}{|l|}{ Schooling } \\
\hline Illiterate & 16.1 & 7.5 & 14.9 & 9.5 & 12.4 \\
\hline Primary school & 24.3 & 17.6 & 37.7 & 26.9 & 26.8 \\
\hline Secondary school & 11.9 & 11.5 & 14.3 & 10.6 & 12.3 \\
\hline High school & 14.8 & 17.5 & 10.4 & 5.3 & 12.7 \\
\hline University degree & 8.0 & 12.4 & 4.3 & 1.3 & 7.0 \\
\hline Missing data & 0.9 & 33.5 & 18.3 & 46.4 & 28.7 \\
\hline \multicolumn{6}{|l|}{ Marital status } \\
\hline Married or partnership & 48.3 & 39.8 & 54.5 & 38.0 & 46.2 \\
\hline Single or divorced & 11.9 & 12.6 & 7.9 & 4.5 & 9.7 \\
\hline Widow & 14.2 & 12.8 & 2.9 & 7.1 & 13.0 \\
\hline Missing data & 25.6 & 34.7 & 22.3 & 50.4 & 31.0 \\
\hline \multicolumn{6}{|l|}{ Employment status } \\
\hline Housewife & 32.7 & 26.1 & 35.3 & 17.7 & 29.3 \\
\hline Employed & 19.3 & 16.3 & 19.6 & 12.6 & 17.5 \\
\hline Unemployed & 0.1 & 0.2 & 0.1 & 0.4 & 0.2 \\
\hline Retired & 11.9 & 12.0 & 11.4 & 3.1 & 10.4 \\
\hline Missing data & 36.0 & 45.4 & 33.6 & 66.2 & 42.6 \\
\hline \multicolumn{6}{|l|}{ Insurance status } \\
\hline Subscriber & 24.0 & 25.9 & 20.6 & 22.4 & 23.3 \\
\hline Dependent & 76.0 & 74.1 & 79.4 & 77.6 & 76.7 \\
\hline
\end{tabular}

Source: Family medicine clinics 2009 electronic health record information.

hypertension were prescribed ACE inhibitors; $43 \%$ of patients with risk factors for cardiovascular events received prophylactic acetylsalicylic acid; and $48 \%$ of those with hypercholesterolemia received a statin.

Approximately $62 \%$ of patients had registered results of blood glucose and total cholesterol tests during 2009; among those without this information, $22 \%$ did not have a glucose and cholesterol test orders and 16\% had the laboratory order registered, but these patients did not attend to the laboratory. After comparing the characteristics of patients with and without laboratory tests, we did not find statistically significant differences regarding sex, age, literacy or occupation, or co-morbidity. Differences were observed in relation to 
Table 4 Clinical conditions and health care characteristics

\begin{tabular}{|c|c|c|c|c|c|}
\hline Medical history & 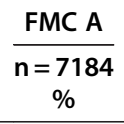 & $\begin{array}{c}\text { FMC B } \\
n=6671 \\
\%\end{array}$ & 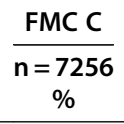 & $\begin{array}{c}\text { FMC D } \\
n=4019 \\
\%\end{array}$ & $\frac{\text { Total }}{\mathrm{n}=\underset{25130}{\%}}$ \\
\hline \multicolumn{6}{|l|}{ Duration of diabetes } \\
\hline$<5$ years & 3.8 & 2.5 & 1.6 & 0.9 & 2.4 \\
\hline $5-10$ years & 12.3 & 6.8 & 5.3 & 10.3 & 8.5 \\
\hline $11-15$ years & 11.6 & 7.3 & 5.2 & 7.5 & 7.9 \\
\hline$>15$ years & 27.5 & 14.8 & 10.6 & 11.1 & 16.6 \\
\hline Missing data & 44.8 & 68.6 & 77.3 & 70.2 & 64.5 \\
\hline \multicolumn{6}{|l|}{ Comorbidity and chronic complications } \\
\hline Hypertensive disease & 63.3 & 68.0 & 59.2 & 44.5 & 60.4 \\
\hline Other cardio-vascular disease & 11.2 & 13.2 & $6.1)$ & 4.2 & 9.2 \\
\hline Hyperlipidemia & 49.2 & 44.3 & 40.2 & 26.1 & 41.6 \\
\hline Diabetic chronic complications & 29.9 & 29.5 & 38.1 & 27.0 & 31.7 \\
\hline \multicolumn{6}{|l|}{ Type of chronic complication } \\
\hline Peripheral vascular disease & 8.9 & 6.8 & 26.8 & 14.9 & 14.5 \\
\hline Diabetic nephropathy & 14.5 & 10.4 & 8.1 & 8.2 & 10.6 \\
\hline Diabetic retinopathy & 7.0 & 12.1 & 6.8 & 4.4 & 7.9 \\
\hline Peripheral neuropathy & 5.6 & 6.0 & 3.6 & 4.3 & 4.9 \\
\hline \multicolumn{6}{|l|}{ Nutritional status } \\
\hline \multicolumn{6}{|l|}{ Nutritional status at the end of the year } \\
\hline Under weight $\left(<18.5 \mathrm{~kg} / \mathrm{m}^{2}\right)$ & 0.3 & 0.5 & 0.2 & 0.3 & 0.3 \\
\hline Normal weight (BMI18.5- $24.9 \mathrm{~kg} / \mathrm{m}^{2}$ ) & 16.4 & 17.9 & 14.2 & 13.5 & 15.7 \\
\hline Overweight (BMI $25.0-29.9$ kg/m²) & 35.8 & 35.4 & 36.3 & 36.2 & 35.9 \\
\hline Obesity (BMI $\geq 30.0 \mathrm{~kg} / \mathrm{m}^{2}$ ) & 33.9 & 31.7 & 35.3 & 34.2 & 33.8 \\
\hline Missing data & 13.6 & 14.5 & 14.0 & 15.8 & 14.3 \\
\hline \multicolumn{6}{|l|}{ Health care characteristics } \\
\hline $\begin{array}{l}\text { Number of visits of the patient to the family doctor, } \\
\text { mean (standard deviation) }\end{array}$ & $8.5(4.4)$ & $9.6(5.0)$ & $8.7(4.5)$ & $7.9(4.1)$ & $8.8(4.6)$ \\
\hline \multicolumn{6}{|l|}{ Hypoglycemic prescriptions } \\
\hline \multicolumn{6}{|l|}{ Number of hypoglycemic prescriptions } \\
\hline None & 20.5 & 18.8 & 14.1 & 9.9 & 16.5 \\
\hline 1 & 37.1 & 40.9 & 32.3 & 34.0 & 36.2 \\
\hline 2 & 38.1 & 37.2 & 43.0 & 46.9 & 40.7 \\
\hline$\geq 3$ & 4.3 & 3.1 & 10.5 & 9.1 & 6.5 \\
\hline \multicolumn{6}{|l|}{ Type of hypoglycemic drugs } \\
\hline Metformin & 57.2 & 62.3 & 65.3 & 67.1 & 37.5 \\
\hline Glibenclamide & 51.8 & 46.9 & 58.7 & 61.7 & 45.9 \\
\hline Acarbose & 3.3 & 3.2 & 12.5 & 9.7 & 7.0 \\
\hline Thiazolidinedione & 0.0 & 0.0 & 1.5 & 0.0 & 0.4 \\
\hline Insulin & 14.1 & 12.4 & 12.5 & 17.4 & 13.7 \\
\hline
\end{tabular}

Source: Family medicine clinics 2009 electronic health record information.

the number of medical visits to a family doctor, as a higher proportion of patients without laboratory exams had only 1 or 2 visits per year $(1.2 \%$ overall and $21.5 \%$ among patients without laboratory results) (Data not included in the table).
Among patients with laboratory exams, few had achieved desired health outcomes: $23 \%$ had HbA1c $<7 \%$ or fasting glucose $\leq 130 \mathrm{mg} / \mathrm{dl}$ in the last 3 measurements; $52 \%$ had total cholesterol $<200 \mathrm{mg} / \mathrm{dl}$ in the last 
Table 5 Indicators of quality of care

\begin{tabular}{|c|c|c|c|c|c|}
\hline Indicators & FMC A & FMC B & FMC C & FMC D & Total \\
\hline I. Process of care & $\begin{array}{c}\mathrm{n}=7184 \\
\%\end{array}$ & $\begin{array}{c}\mathrm{n}=6671 \\
\%\end{array}$ & $\begin{array}{c}n=7256 \\
\%\end{array}$ & $\begin{array}{c}\mathrm{n}=4019 \\
\%\end{array}$ & $\begin{aligned} n= & 25130 \\
& \%\end{aligned}$ \\
\hline \multicolumn{6}{|l|}{ A. Timely detection of T2D complications and comorbidity in the last year } \\
\hline At least one measurement of $\mathrm{HbA1c}$ & 9.0 & 16.9 & Not available & Not available & 7.1 \\
\hline Comprehensive foot evaluation & 51.9 & 28.2 & 24.6 & 5.4 & 30.3 \\
\hline Referral to the ophthalmologist & 22.2 & 14.2 & 7.0 & 5.4 & 13.0 \\
\hline \multirow{2}{*}{$\begin{array}{l}\text { Screening for dyslipidemia by measuring total cholesterol in } \\
\text { patients without previous diagnosis of dyslipidemia }\end{array}$} & 3653 & 3714 & 4336 & 2971 & 14674 \\
\hline & 65.4 & 54.7 & 45.6 & 70.0 & 57.8 \\
\hline \multirow[t]{2}{*}{ B. Non-pharmacological treatment in the last year } & $\mathbf{n}$ & $\mathbf{n}$ & $\mathbf{n}$ & $\mathbf{n}$ & $\mathrm{n}$ \\
\hline & $\%$ & $\%$ & $\%$ & $\%$ & $\%$ \\
\hline \multirow[t]{2}{*}{ Nutritional counseling provided by the nutrition service } & 7184 & 6671 & 7256 & 4019 & 25130 \\
\hline & 1.8 & 5.5 & 4.9 & 3.0 & 3.9 \\
\hline \multirow[t]{2}{*}{ C. Pharmacological treatment in the last three visits } & $\mathbf{n}$ & $\mathbf{n}$ & $\mathbf{n}$ & $\mathrm{n}$ & $\mathbf{n}$ \\
\hline & $\%$ & $\%$ & $\%$ & $\%$ & $\%$ \\
\hline \multirow{2}{*}{$\begin{array}{l}\text { Overweight/obese (BMl } \geq 25 \mathrm{~kg} / \mathrm{m}^{2} \text { ) patients who received metformin, } \\
\text { unless contraindicated }\end{array}$} & 5066 & 4437 & 5216 & 2840 & 17559 \\
\hline & 57.2 & 63.0 & 66.7 & 67.6 & 63.2 \\
\hline \multirow{2}{*}{$\begin{array}{l}\text { Patients with hypertension receiving inhibitors of angiotensin converting } \\
\text { enzyme or angiotensin-receptor blocker, unless contraindicated }\end{array}$} & 4545 & 4536 & 4298 & 1787 & 15172 \\
\hline & 46.0 & 56.8 & 58.9 & 66.1 & 57.4 \\
\hline \multirow{2}{*}{$\begin{array}{l}\text { Patients }>40 \text { years of age with one or more of the following risk factors: } \\
\text { smoking, hypertension, dyslipidemia, receiving } 75-150 \mathrm{mg} / \text { day of } \\
\text { acetylsalicylic acid, unless contraindicated }\end{array}$} & 5242 & 5035 & 4904 & 2076 & 17257 \\
\hline & 45.8 & 32.0 & 46.2 & 58.9 & 43.4 \\
\hline \multirow{2}{*}{$\begin{array}{l}\text { Patient with total cholesterol > } 200 \mathrm{mg} / \mathrm{dl} \text { and were prescribed statins, } \\
\text { unless contraindicated }\end{array}$} & 2436 & 1998 & 2197 & 1233 & 7864 \\
\hline & 55.6 & 43.9 & 49.1 & 36.9 & 47.9 \\
\hline \multirow[t]{2}{*}{ II. Health outcomes } & $\mathrm{n}$ & $\mathrm{n}$ & $\mathrm{n}$ & $\mathrm{n}$ & $\mathrm{n}$ \\
\hline & $\%$ & $\%$ & $\%$ & $\%$ & $\%$ \\
\hline \multirow[t]{2}{*}{$\mathrm{HbA1c}<7 \%$ or fasting glucose $\leq 130 \mathrm{mg} / \mathrm{dl}$ in the last 3 measurements } & 4644 & 3560 & 4563 & 2816 & 15583 \\
\hline & 23.0 & 32.5 & 19.2 & 17.9 & 23.1 \\
\hline \multirow[t]{2}{*}{ Total cholesterol levels $<200 \mathrm{mg} / \mathrm{dl}$ in the last measurement } & 5097 & 4168 & 4125 & 3008 & 16398 \\
\hline & 52.2 & 52.1 & 46.7 & 59.0 & 52.0 \\
\hline \multirow[t]{2}{*}{ Blood pressure $<130 / 80 \mathrm{mmHg}$ in the last 3 measurements } & 7088 & 6587 & 7247 & 4011 & 24933 \\
\hline & 12.3 & 8.5 & 14.1 & 5.7 & 10.8 \\
\hline \multirow{2}{*}{$\begin{array}{l}\text { Overweight/obese (BMl } \geq 25 \mathrm{~kg} / \mathrm{m} 2 \text { ) patients who lost } \geq 5 \% \text { body } \\
\text { weight in the last year }\end{array}$} & 5066 & 4437 & 5216 & 2840 & 17559 \\
\hline & 13.4 & 14.7 & 12.6 & 12.5 & 13.3 \\
\hline \multirow{2}{*}{$\begin{array}{l}\text { Patients with } \mathrm{HbA} 1 \mathrm{c}<7 \% \text {, or fasting glucose } \leq 130 \mathrm{mg} / \mathrm{dl} \text {, total cholesterol } \\
\text { levels }<200 \mathrm{mg} / \mathrm{dl} \text { and blood pressure }<130 / 80 \mathrm{mmHg} \text { in the last } \\
3 \text { measurements }\end{array}$} & 4272 & 3123 & 3479 & 2516 & 13390 \\
\hline & 1.8 & 1.7 & 1.2 & 0.6 & 1.4 \\
\hline
\end{tabular}

Source: Family medicine clinics information from 2009 electronic health record. The analysis included 12 months.

measurement; $11 \%$ had blood pressure $<130 / 80 \mathrm{mmHg}$ in the last 3 measurements; $13 \%$ of overweight or obese patients had lost $\geq 5 \%$ body weight in the last year; and only $1 \%$ of patients reached the combined therapy goals for blood glucose, cholesterol and blood pressure control.

\section{Discussion}

Our results suggest that it is feasible to a) develop T2DM QCIs applicable in the context of a middle-income country; b) measure the QCIs using routinely collected data from a widely implemented EHR system; and c) identify aspects of care for T2DM patients that are in need of improvement. Our work highlights the potential of routine EHR data to contribute to chronic care quality improvement, as well as the need for attention to the quality and completeness of electronic data. These findings are important in the global context of rapidly increasing prevalence of chronic conditions, particularly in low and middle-income countries, which require regular monitoring of processes and outcomes of care to ensure wise use 
of scarce resources. They also highlight the potential but less than optimal uses of electronic health information systems for routine monitoring of care processes and outcomes [22,23].

\section{A) QCls in the context of a middle-income country health care system}

Most published QCIs have been constructed for healthcare systems in high-income countries. Using the same QCIs across countries would facilitate international comparisons [24]. However, QCIs should be adjusted according to national variations in financing, structure, and provision of healthcare services, and differences in the characteristics of populations across countries. We originally intended to adopt the HEDIS indicators [18] used by more than $90 \%$ of America's health plans to measure performance of care and services. However, since HbA1c, LDL-cholesterol tests and nephropathy screening are not established standards at IMSS family medicine clinics, we needed to develop contextually suitable indicators. Our process for developing, measuring, validating, and reporting QC indicators may be informative in other developing countries.

\section{B) measuring QCls using routinely collected data from a widely implemented EHR system}

The EHR did not contain all data elements needed to identify the denominator population of members with diabetes or to construct the identified QCIs. Clinical services at IMSS' FMCs are almost paperless; all information is electronically stored. Our results indicate that there are shortcomings in the electronic information, possibly related to flaws in its design and the limited use of some EHR fields. While we generated rules and algorithms to identify plausible values and exclude records with missing values from the analysis, it is crucial for IMSS to improve its electronic record system for quality monitoring to become a routine process. This would include maintaining a reliable registry of patients with important chronic illnesses like diabetes.

We used a conservative approach to manage missing data, by not including cases with missing information in the analysis. This decision was supported by results from comparisons of socio-demographic characteristics of patients with and without laboratory results, which did not have statistically significant differences; we also took into account that the size of the sample was large, thus reducing the number of cases would not reduce statistical power. However, the validity and generalizability of our results are limited to the extent that there was bias in exclusion of members without visits during the observation year or without data needed to measure QCIs.

To progress to a robust eHealth system, it will be necessary to analyze in-depth the functionality and quality of the EHR, develop decision-support systems, and strengthen linkages between the EHR and other electronic applications, such as laboratory and pharmacy databases.

\section{C) identifying aspects of diabetes care in need of improvement}

Complex healthcare institutions require ongoing evaluation of their performance. In Mexico, evaluating QC based on EHR data is novel and promising, given the high cost, lengthy process, and lack of scale of more typical paper-based evaluations. The lack of complete data notwithstanding, we identified important aspects of care that require improvement. IMSS clinics have low rates of use of diagnostic tests, including $\mathrm{HbA} 1 \mathrm{c}$, microalbuminuria screening and LDL-cholesterol. IMSS' current model of care relies heavily on family medicine doctors. As our results show, patients have limited access to dietitians, social workers, nurses and other specialists, hindering the integrated multi-specialty care patients with chronic conditions require to ensure the best possible outcomes [25,26].

Our results are comparable to those from studies within Mexico and elsewhere. In a study conducted in Mexico, $66.3 \%$ of T2DM patients did not have good metabolic control, although those with access to healthcare had better health outcomes. The European Core Indicators Diabetes Project included 19 countries [27]; its results showed wide variability in QCIs among them: HbA1c testing ranged from $51 \%$ (Ireland) to 99\% (France and the Netherlands); lipid measurements from $45 \%$ (Ireland) to $99 \%$ (the Netherlands); and eye examinations from $12 \%$ (Ireland) to $84 \%$ (The Netherlands). In India, only $13 \%$ of T2DM patients had at least one HbA1c measurement, $16.2 \%$ had an eye examination, $3.1 \%$ foot examination, $8.3 \%$ nutritional counseling, 32.1\% serum cholesterol estimation and $17.5 \%$ were prescribed aspirin; [28]. Rates of $\mathrm{HbA} 1 \mathrm{c}>7 \%$ varied from $32 \%$ (Ireland) to $83 \%$ (Cyprus); total cholesterol $>5$ $\mathrm{mmol} / \mathrm{l}$ ranged from $14 \%$ (Ireland) to 68\% (Cyprus); blood pressure $>140 / 90 \mathrm{mmHg}$, from $17 \%$ (France) to $46 \%$ (Sweden). [27] The QUALIDIAB network [29] in Argentina, Brazil, Chile, Colombia, Paraguay, and Uruguay reported that $43 \%$ of patients had blood glucose level of $<7.7 \mathrm{mmol} / \mathrm{L}$ and the proportion of patients reaching combined treatment goals for blood glucose, cholesterol and blood pressure ranged from $1 \%$ in Mexico to almost $12 \%$ in the United States [30]. These variations should give rise to continued assessment and improvement efforts.

While this study included information from only four clinics, we found important differences between them; for example, two clinics did not have HbA1c data, pointing to heterogeneity in care processes even within the same health delivery system. Further research studies should examine ways to reduce these differences. Although the study clinics may not represent the QC that 
IMSS provides, results from desk-based medical chart reviews (with smaller sample sizes) are similar [4,5].

Our results will serve as input to subsequent improvements of the IMSS EHR. The health system in which the EHR is used has a heavy clinical workload (20-25 patients per doctor per 6 hours of consultations, or 15-18 minutes per patient). In this context, the EHR can either hinder or facilitate care. The EHR was originally designed to gather routine clinical information to facilitate the daily work of family doctors and yield epidemiological information. Our study supports the notion that data from the EHR can be used to evaluate quality of care. Further, the EHR could potentially serve other purposes, such as a decision support system to guide clinicians through gathering relevant patient information, including risk factors and health status, and provide drug dosing guidelines and support tools. However the IMSS EHR does not yet include decision support systems. These should be developed as part of the advancement of the EHR. The experience of Mexico in the use of the EHR to evaluate quality of care can be of value for other low and middle-income countries that aim to improve their e-health capabilities.

\section{Conclusions}

This study demonstrated that it was feasible to evaluate QC for T2DM patients by using EHR data. Evaluating QC using EHR information can identify the performance of individual clinics or individual providers, guide future interventions aimed at improving $\mathrm{QC}$ and evaluate whether these interventions achieve their expected aims.

A well designed EHR, which should include rigorous data-entry and data quality monitoring would improve the capabilities to evaluate and monitor processes and outcomes of care, which in turn would provide useful feedback to authorities, healthcare personnel and patients. It also can serve to make comparisons among clinics, health care systems or countries.

From the clinicians' perspective, EHR design and use should improve its functionality for the daily work, for example as a clinical decision-making tool, and as a reliable source to provide feedback to the providers.

\section{Competing interests}

The authors declare that they have no competing interests.

\section{Acknowledgments}

We thank the medical directors of the participating clinics for their collaboration in the study. We appreciate the panel of experts who participated in the rating of quality of care indicators.

\section{Author details}

'Division of Social Protection and Health, Inter-American Development Bank, Washignton, USA. ${ }^{2}$ Epidemiology and Health Services Research Unit CMN Siglo XXI, Mexican Institute of Social Security, México, DF, Mexico. ${ }^{3}$ Centre for Health Services and Policy Research, School of Population and Public Health, The University of British Columbia, Vancouver, Canada. ${ }^{4}$ Department of Population Medicine and WHO Collaborating Center in Pharmaceutical Policy, Harvard Medical School and Harvard Pilgrim Health Care Institute,
Boston, MA, USA. ${ }^{5}$ Unidad de Investigación en Epidemiología Clínica, Hospital Regional 1 Carlos MacGregor Sánchez Navarro, IMSS, México, DF, México. ${ }^{6}$ División de Innovación de la Coordinación de Educación en Salud, IMSS, México, DF, Mexico.

\section{Authors' contributions}

RPC conceptualized and designed the study, coordinated the fieldwork and wrote the article. SVD conducted the literature review, coordinated the development, definitions, and programming of the indicators, conducted the statistical analysis, and interpreted the data and contributed to drafting the article. MSO programmed the indicators and collaborated on the analysis; $\mathrm{ML}$ participated in assessing data quality and programming the indicators and reviewed critically the results and paper. AHP participated in the development of the study. JE and FEL participated in the design of the indicators and reviewed the paper for significant intellectual content. DR-D collaborated on conceptualizing and designing the study, participated in the development of the study and critically reviewed the paper. AKW

collaborated on conceptualizing and designing the study, participated in the development of the study, reviewed the results and contributed to drafting the article. All authors approved the final manuscript.

The opinions expressed are those of the authors and do not necessarily represent the views of their institutions.

Received: 30 November 2011 Accepted: 6 June 2012

Published: 6 June 2012

\section{References}

1. Villalpando S, Shamah-Levy T, Rojas R, Aguilar-Salinas CA: Trends for type 2 diabetes and other cardiovascular risk factors in Mexico from 1993-2006. Salud Publica Mex 2010, 52:S72-S79. suppl 1.

2. Shaw JE, Sicree RA, Zimmet PZ: Global estimates of the prevalence of diabetes for 2010 and 2030. Diabetes Res Clin Pract 2010, 87:4-14.

3. Rulla JA, Aguilar-Salinas C, Rojas R, Rios-Torres JM, Gómez-Pérez FJ, Olaiz G: Epidemiology of type 2 diabetes in Mexico. Arch Intern Med 2005, 36:188-196.

4. Salinas-Martínez AM, Amaya-Alemán MA, Arteaga-García JC, Núñez-Rocha GM, Garza-Elizondo ME: Technical efficiency in primary care for patients with diabetes. Salud Publica Mex 2009, 51:48-58.

5. Díaz-Apodaca BA, de Cosío FG, Canela-Soler J, Ruiz-Holguín R, Cerqueira MT: Quality of diabetes care: a cross-sectional study of adults of Hispanic origin across and along the United States-Mexico border. Rev Panam Salud Publica 2010, 28:207-213.

6. Vázquez-Martínez JL, Gómez-Dantés H, Fernández-Cantón S: Diabetes mellitus en población adulta del IMSS. Resultados de la Encuesta Nacional de Salud 2000. Rev Med Inst Mex Seguro Soc 2006, 44:13-26.

7. Arredondo A, Zuñiga A: Economic Consequences of Epidemiological Changes in Diabetes in Middle-Income Countries: The case of Mexico. Diabetes Care 2004, 27:104-109.

8. McGlynn EA, Damberg CL, Kerr EA, Brook RH: Health Information Systems Design Issues and Analytic Applications. Santa Monica: Rand Health; 1998.

9. Car J, Black A, Anandan C, Cresswell K, Pagliari C, McKinstry B, Procter R, Majeed A, Sheikh A: The impact of eHealth on the quality and safety of healthcare. In A Systemic Overview \& Synthesis of the Literature Report for the NHS Connecting for Health Evaluation Programme; 2008. Available at: http:/www.haps.

10. Fernández A, Oviedo E: Salud electrónica en América Latina y el Caribe: avances y desafíos. Santiago de Chile: CEPAL; 2010.

11. Williams F, Boren SA: The role of the electronic medical record (EMR) in care delivery development in developing countries: a systematic review. Inform Prim Care 2008, 16:139-145.

12. Pérez-Cuevas R, Ruiz B, Reyes $H$, Pedrote B, Massa R, Vargas $L$, Sánchez $L$, Estrada C, Michaus F, Castro A, Muñoz O: Implementation and evaluation of the Family Medicine Improvement Process experimental model. In Family medicine at the dawn of the 21st Century. Edited by García-Peña C, Muñoz O, Durán L. Mexico: IMSS; 2005:55-74.

13. Brook RH, Chassin MR, Fink A, Solomon DH, Kosecoff J, Park RE: A method for the detailed assessment of the appropriateness of medical technologies. Inn J Technol Assess Health Care 1986, 2:53-63.

14. Campbell SM, Hann M, Hacker J, Roland MO: Quality assessment for three common conditions in primary care: validity and reliability of review criteria developed by expert panels for angina, asthma and type 2 diabetes. Qual Saf Health Care 2002, 11:125-130. 
15. Marshall M, Roland M, Campbell S, Jirk S, Reeves D, Brook R, Shekelle PG: Measuring general practice. A demonstration project to develop and test a set of primary care quality indicators. London: The Nuffield Trust; 2003.

16. Instituto Mexicano del Seguro Social. Dirección de Prestaciones Médicas: Guía de Práctica Clínica para el Diagnóstico y Tratamiento de la Diabetes mellitus tipo 2 en el Primer Nivel de Atención. México DF:: 2009.

17. Saslow D, Runowicz CD, Solomon D, Moscicki AB, Smith RA, Eyre HJ, Cohen C: American Cancer Society Guideline for the Early Detection of Cervical Neoplasia and Cancer. CA Cancer J Clin 2002, 52:342-362.

18. National Committee for Quality Assurance: HEDIS 2010 vol. 2 Technical specifications for Physician Measurement. Washington DC: NCQA; 2010.

19. Shekelle PG, MacLean CH, Morton SC, Wenger NS: Assessing care of vulnerable elders: methods for developing quality indicators. Ann Intern Med 2001, 135:647-652.

20. Chobanian AV, Bakris GL, Black HR, Cushman WC, Green LA, Izzo JL, Jones DW, Materson BJ, Oparil S, Wright JT, Roccella EJ: Seventh report of the Joint National Committee on Prevention, Detection, Evaluation, and Treatment of High Blood Pressure. Hypertension 2003, 42:1206-1252.

21. McDowell MA, Fryar CD, Ogden CL, Flegal KM: Anthropometric Reference Data for Children and Adults: United States, 2003-2006. In National health statistics reports; no 10. Hyattsville, MD: National Center for Health Statistics; 2008.

22. O'Connor P, Crain AL, Rush W, Sperl-Hillen J, Gutenkauf J, Duncan J: Impact of Electronic Medical Record on Diabetes Quality of Care. Ann Fam Med 2005, 3:300-306.

23. Fraser HS, Blaya J: Implementing medical information systems in developing countries, what works and what doesn't. AMIA Annu Symp Proc 2010, 2010:232-236

24. Steel N, Melzer D, Shekelle PG, Wenger NS, Forsyth D, McWilliams BC: Developing quality indicators for older adults: transfer from the USA to the UK is feasible. Qual Saf Health Care 2004, 13:260-264.

25. Pérez-Cuevas R, Reyes-Morales H, Doubova SV, Zepeda Arias M, Díaz Rodríguez G, Peña Valdovinos A, Muñoz Hernández O: Comprehensive diabetic and hypertensive patient care involving nurses working in family practice. Rev Panam Salud Publica 2009, 26:511-517.

26. Ortiz-Domínguez ME, Garrido-Latorre F, Orozco R, Pineda-Pérez D, Rodríguez-Salgado M: Sistema de Protección Social en Salud y calidad de la atención de hipertensión arterial y diabetes mellitus en centros de salud. Salud Publica Mex 2011, 53:S436-S444.

27. EuCID: Final Report European Core Indicators in Diabetes Project:; 2008. Available at: http://ec.europa.eu/health/ph_projects/2005/action1/docs/ action1_2005_frep_11_en.pf.

28. Nagpal J, Bhartia A: Quality of diabetes care in the middle- and highincome group populace: the Delhi Diabetes Community (DEDICOM) survey. Diabetes Care 2006, 29:2341-2348.

29. Gagliardino JJ, de la Hera M, Siri F, Grupo de Investigación de la Red QUALIDIAB: Evaluation of the quality of care for diabetic patients in Latin America. Rev Panam Salud Publica 2010, 10:309-317.

30. Gakidou E, Mallinger L, Abbott-Klafter J, Guerrero R, Villalpando S, Ridaura RL, Aekplakorn W, Naghavi M, Lim S, Lozano R, Murray CJ: Management of diabetes and associated cardiovascular risk factors in seven countries: a comparison of data from national health examination surveys. Bull World Health Organ 2011, 89:172-183.

\section{doi:10.1186/1472-6947-12-50}

Cite this article as: Pérez-Cuevas et al:: Evaluating quality of care for patients with type 2 diabetes using electronic health record information in Mexico. BMC Medical Informatics and Decision Making 2012 12:50.

\section{Submit your next manuscript to BioMed Central and take full advantage of:}

- Convenient online submission

- Thorough peer review

- No space constraints or color figure charges

- Immediate publication on acceptance

- Inclusion in PubMed, CAS, Scopus and Google Scholar

- Research which is freely available for redistribution

Submit your manuscript at www.biomedcentral.com/submit 